\title{
13
}

\section{Outsourcing Legal Aid in the Nordic Welfare States}

\section{Ole Hammerslev and Olaf Halvorsen Rønning}

\section{Introduction}

The Nordic countries have as a common characteristic the ideology of universal welfare. The Nordic welfare states were, largely, built through comprehensive written law, giving all citizens clearly defined rights, and entitling them to receive specific, but equal and sufficient, benefits. Public authorities advised citizens about their welfare rights and ensured they got them. However, the increasing complexity of welfare rights and of regulation, and increasing bureaucracy meant that that poor people in particular, but ordinary people too, had difficulty in naming their social problems legally, and

O. Hammerslev $(\bowtie)$

Department of Law, University of Southern Denmark, Odense M, Denmark

Department of Criminology and Sociology of Law, University of Oslo, Oslo, Norway

O.H. Rønning

Department of Criminology and Sociology of Law, University of Oslo,

Oslo, Norway

(C) The Author(s) 2018

O. Halvorsen Rønning, O. Hammerslev (eds.), Outsourcing Legal Aid

in the Nordic Welfare States, https://doi.org/10.1007/978-3-319-46684-2_13 
claiming their rights either from public bodies or in court. Thus, even though legal services in all Nordic countries were based primarily on market assumptions, legal aid schemes became-as part of the universal welfare state ideology — ways to ensure people could claim their welfare rights.

One feature of civil legal aid schemes in all the Nordic countries is this backdrop of the universal welfare state ideology; it is the context in which the legal aid schemes have been understood. This includes, to a certain extent, the ideological component of the schemes, namely that they all have the same social democratic welfare state core. In the earliest stages of the modern legal aid schemes, public legal aid in all Nordic countries was an informally governed, discretionary feature of social security, and could be granted if deemed necessary. The schemes focused on legal aid in court cases. It was to some extent an addition to charitable legal aid, such as that provided by church organisations, for example, but the aid given by such organisations was limited. The next stage came with the development of formal legal aid legislation, from the 1950s onwards. Although the actual implementation of their legal aid acts varied, all Nordic countries enacted welfare state-inspired legal aid legislation, which set up quite generous schemes with the aim to improve legal aid, and ensure access to the courts and legal services for all. Finland was first, passing a new Legal Aid Act in 1953, and, in 1973, developing a more extensive and very clearly welfare state-inspired system. Sweden followed suit in 1972, Denmark in 1974, and Norway in 1980. Such legislation was never passed in Iceland, but a similar act was brought before Parliament. Of these, the Norwegian Act was originally extraordinarily generous: for example, it granted legal aid outside court proceedings to all who met the financial criteria, unless they could not benefit from legal aid assistance. Similarly, the Swedish scheme of the time has been characterised as 'probably the most generous and comprehensive scheme internationally' (Kilian and Regan 2004, p. 247).

The chapters making up this book show how civil legal aid schemes are structured in the modern Nordic welfare states, and demonstrate the different ways the schemes have developed in each Nordic country. The core welfare state component in the public legal aid schemes remains but to a varying degree. The public legal aid schemes are managed as welfare state institutions and have been heavily state-funded. In fact, the Nordic countries are consistently among the nations in Europe spending most on legal aid per inhabitant. Drawing on national reports, we will discuss whether a 
uniquely Nordic model of legal aid exists. To place the Nordic schemes in the European and international context, similarities and differences between the Nordic countries are analysed by comparing their legal aid schemes and relating them to international legal aid developments. The findings will also be related to discussions about general developments in the welfare state. Through case studies of prominent third sector legal aid organisations and mentoring programmes, we have considered the difficulties involved in reaching marginalised target groups, how third sector institutions have organised legal aid outside the welfare state, and how they help marginalised individuals to name, blame, and claim - to adopt the notions of Felstiner et al. (1980/81) — their rights from public authorities, in particular. Because of a shift in modern Nordic welfare states towards third sector organisations, and the insurance market, third sector organisations have become more important in reaching groups in society with special needs, and are able to manoeuvre in ways that public organisations cannot. Finally, based on these case studies, we discuss how the changing role of the law and the possibility of legal encounters between citizens, and caseworkers, lawyers, public officials, etc. affect the most vulnerable groups in welfare societies.

\section{Legal Aid in the Nordic Countries}

We will now, on the basis of the reports on the five countries, make a comparison between legal aid in the Nordic countries and discuss whether it is possible to identify a Nordic model of legal aid.

By international standards, Norway is financially the most generous provider of legal aid assistance per inhabitant. In Chap. 2, Rønning shows that the Norwegian state funds legal aid primarily through judicare schemes, in which paid lawyers in private practice provide legal aid to people who are granted legal aid. Eligibility for legal aid in civil cases is determined by financial criteria, which have to be met to obtain aid in the civil areas listed in the Legal Aid Act. These areas include divorce, social security, immigration, and unfair dismissal. However, the income limits for financial eligibility for legal aid have been stable, although average salaries have increased over time. The scheme only covers legal aid in cases where no other assistance is provided. This limitation mostly rules out legal aid assistance in administrative matters, because public officials are obligated to give 
guidance, under the Norwegian Administrative Procedure Act. Norwegian legal aid research has criticised the scheme for being too restrictive, and therefore not meeting the legal needs of the population. Many people from the most disadvantaged groups will have frequent legal conflicts with administrative bodies but, under this rule, will be excluded from the scheme. However, in addition to the public judicare scheme, there are quite a few alternative legal aid providers. Some involve the commercial provision of legal assistance, such as legal aid insurance, while some are non-profit initiatives. These are oriented around student legal aid clinics, such as Juss-Buss, described by Hammerslev et al. in Chap. 7, special interest organisations providing legal aid to specific groups such as asylum seekers or drug users, consumer organisations, and labour unions. Some are fully or partly state-funded but managed independently.

In Chap. 3, Schoultz shows how the Swedish legal aid schemes that came into force in the 1970s were part of a universal welfare programme designed to compensate for financial differences by providing comprehensive legal aid via state-financed legal bureaus with more than a hundred public-sector lawyers. However, to reduce spending on legal aid, new legislation changed the system in the 1990s. The reform made legal aid schemes subordinate to private legal aid insurance, and the statefinanced legal aid bureaus were closed and replaced by a judicare system. Schoultz demonstrates that this fundamental change meant that the current legal aid schemes went from being tax-funded to being mainly provided through private insurance. The shift towards insurance only covered legal cases conducted in court, and, thus limited the type of legal aid services provided. Legal aid other than for court proceedings is limited, both in terms of legal expenses insurance and of public legal aid. In principle, all legal matters qualify for public legal aid, but the Legal Aid Act excludes things such as debt restructuring, most family law disputes, and the preparation of tax returns, wills, and prenuptial agreements. The legal aid scheme also makes individuals responsible for identifying and naming legal problems, and for paying for legal assistance, which may be reimbursed later. Because of the high cost of legal consultation, which is a prerequisite for applying for legal aid, people get discouraged from seeking advice. Citizens, moreover, face the very real burden of naming a social problem and turning it into a legal issue, in order to apply for legal 
aid. This transformation process is identified in previous studies as particularly challenging for the most socially disadvantaged groups. The 'cut down' reforms of the 1990s brought back the need for pro bono work by lawyers (Regan 2001), in the same way that students' legal clinics developed. The reform of legal aid policy has left some needy groups without any legal help: for example, those with moderate means, who do not have legal expenses insurance, are not poor enough to qualify for legal aid, and not able to afford a private lawyer. The same goes for those with moderate means, who are not eligible for legal aid for work-related problems, and who do not belong to a union.

In Chap. 4, Rissanen shows how legal aid in Finland is organised differently than in the other Nordic countries. Like Swedish legal aid in the 1970s, the current Finnish legal aid system mainly involves publicsector lawyers working in Public Legal Aid (PLA) offices. These offices provide all types of legal aid. In addition to the PLA offices, private lawyers approved by the PLA offices can be funded by the state to represent legal aid clients in court proceedings. The development of the extensive legal aid provision in Finland reflects the welfare state paradigm of equal access to legal aid, irrespective of income. The main reason for supplementing PLA offices with private lawyers was to provide nationwide legal aid, including locations previously not covered by the PLA offices. Rissanen also notes that the PLA offices play an important mediating role between the conflicting parties, thus preventing court proceedings. This extensive public legal aid goes hand in hand with legal aid insurance provided by commercial companies. By comparison with developments elsewhere in the world, the Finnish PLA system has not tightened its legal aid criteria in recent years (regarding, for example, income ceilings or case eligibility). On the contrary, the Finnish PLA system has continued more or less to offer access to justice in a quasi-universal way. With recent budget cuts, however, the number of PLA offices has shrunk, and IT solutions and telephone services are prioritised. The decrease in PLA offices has also meant that a growing number of cases are delegated to private lawyers, but overall, the effects have been slight compared to those in many other European legal aid systems. The main reason that the Finnish legal aid system has been able to maintain its comprehensive coverage is the existence of an 
efficient, integrated, legal aid model, where the PLA offices offer more holistic legal aid, and private lawyers concentrate on legal disputes.

In Chap. 5, Kristiansen shows that, in Denmark, there has been a long tradition of publicly funded legal aid, alongside voluntary offices and legal clinics. With the expanding welfare programmes of the 1960s the goal was to achieve universal access to justice through public funding, and to cover legal costs when cases were brought to court. In addition, pre-trial legal aid was introduced that gave citizens the right to free legal aid by lawyers. Everyone, irrespective of income and the type of legal problem in question, currently has a right to verbal legal aid assistance, with eligibility to further legal aid assessed on mainly financial criteria. In 2014, however, legal action against public authorities was excluded from extended legal aid: verbal advice, drafting letters, writing complaints, or case handling support in the pre-court phase. Instead, the authorities are obligated to assist citizens, as is also the case in Norway. Legal aid is provided by a mix of non-commercial legal aid offices organised by pro bono lawyers and student volunteers in a form of judicare, where lawyers are remunerated for extended legal aid. In 2007, a reform was introduced that ensured citizens easier access to small-claim courts, in which they could represent themselves, with the help of procedural guidance from the courts. As we will discuss below, this is in tune with the access to justice perspective, but it also places a lot of responsibility on citizens, requiring them to be able to name, blame, and claim their rights without any legal help. At the same time, legal aid insurance took on primary importance, so free legal aid is now only available to those without insurance, or those whose insurance does not cover the case. Kristiansen concludes that government-subsidised legal aid provided by lawyers is, in practice, non-existent for the vast majority of the population. However, a number of new non-profit organisations have developed, such as Gadejuristen [The Street Lawyers], as described in Chap. 8. Such organisations as unions and tenant associations provide legal aid to their members, while others offer outreach support to specific target groups, like refugees and abused women.

In Chap. 6, Antonsdottir discusses how, with the legal aid reforms of the 1990s, legal aid in Iceland changed from being a kind of charitable activity supporting the poor and needy, to being the right to access the 
courts irrespective of financial status. In reality, access to legal aid depends on financial criteria. Moreover, a section of the legal aid bill that lays down whether cases of public or individual interest should be eligible for legal aid has been repeatedly taken out by one political wing, and put back in again by the other. Iceland lacks out-of-court legal aid, which is provided instead by membership organisations or the non-profit sector. In the 1990s, legal expenses insurance was introduced, but it usually failed to cover out-of-court legal expenses. There is no official policy on how eligibility for legal aid is assessed in the light of the level of insurance an applicant has, but, as Antonsdottir points out, policyholders get their legal aid applications rejected.

\section{Legal Aid in the Nordic Countries: A Nordic Model?}

This volume makes clear that, as with other general Nordic welfare programmes (Arts and Gelissen 2010; Goul Andersen and Albrekt Larsen 2015), the Nordic countries follow different legal aid models; there are also differences in organisational structure and supply of legal aid. Even though, as discussed above, all the Nordic legal aid schemes have the universal welfare paradigm in the background, the five countries have developed in different directions to compensate for financial cuts, and deal with new requirements for legal aid. Sweden has moved in the direction of a market-based approach, where legal aid is primarily based on insurance. Although the scheme in Sweden was originally based on public legal aid offices, a broad publicly-administered social support scheme, and a strong welfare state ideology, cost cutting measures significantly reduced the state's role in legal aid provision. In consequence, responsibility for ensuring access to legal services was transferred from the state to individuals and the market, via legal expenses insurance. As a result, legal expenses insurance is the main provider of legal aid, and it is up to the individual to approach lawyers and name their legal problems. Finland tries to maintain its opposite position, retaining its welfare state inspired scheme and public legal aid offices. Nevertheless, Finnish legal aid too, is 
complemented by legal aid insurance and has developed IT solutions, to achieve greater efficiency. Denmark and Norway are most alike in their general legal aid schemes: they represent a middle ground between Finland and Sweden, pursuing neither a broader welfare state approach, nor one that is market-based. The public legal aid schemes continued in Norway and Denmark with comparatively little change, although with some cost-saving measures, and some development of alternative legal aid providers. The challenges facing public legal aid in Norway and Denmark have largely been mitigated by third sector legal aid initiatives. Of the Nordic countries, Iceland has the least generous system, and it consists mainly of out-of-court legal aid based on insurance, membership organisations, or voluntary institutions. Research on welfare states suggests that Finland is exceptional, compared to the other Nordic countries, when it comes to welfare programmes (Kongshøj 2015; Arts and Gelissen 2010), and such a view is further supported by the Finnish legal aid model. Developments in Sweden especially, but also in Denmark and Norway, go against universal welfare state ideology, and represent a reconfiguration of the traditional welfare state. Formerly, legal aid programmes were considered a state responsibility, but they have now been outsourced to the market and the third sector.

One issue common to all the Nordic countries is the focus on budget cuts in the wake of developments in Europe and worldwide. Because of this, the five countries are in the process of bringing their approaches into line with those found elsewhere. On the one hand, except in Finland, there has been a move towards outsourcing legal aid to non-profit organisations based on volunteers or membership. On the other hand, legal aid has been commercialised through private insurance. In most of the countries, legal aid insurance is the main provider of legal aid. Such an abdication of the welfare state to the third sector, and privatisation, have also been observed in other areas of welfare, such as the health system, which has increasingly resorted to private health insurance (Kongshøj 2015).

Another dimension of the move of legal aid schemes towards the third sector and membership organisations is the transformation of professional legal hierarchies. The country chapters indicate to varying degrees that it has become less attractive for lawyers to provide legal aid. This development parallels trends in the UK. In all the Nordic countries, legal aid 
lawyers earn less than private lawyers - and markedly less than corporate lawyers, whose salaries are determined by the free market. In Denmark and in Sweden, it is difficult to recruit volunteer lawyers to legal aid offices. There are several structural reasons for this. The most important is the tendency for the larger law firms to be concentrated in big cities, and to specialise in business law. This development is clearly seen in the USA, with most specialised lawyers being employed in the major firms (Galanter and Palay 1991). Lawyers from such firms are not equipped to deal with the kind of legal work required in legal aid offices. Changes in legal hierarchies have also been reported in other Western countries (Sommerlad 2001; Heinz et al. 1998; Sandefur 2001; Moorhead 2004). As is shown by Sommerlad, in England, the legal aid worker has gone from being a kind of cause lawyer - a lawyer with a social face - to being a low status hack lawyer with a massive overload of cases. This has an impact on the quality of legal aid. In the Nordic countries, things have not gone that far, but there is a tendency towards a further marginalisation of legal aid workers and disillusionment with public-sector legal aid.

\section{Third Sector Initiatives}

One key feature of the development of legal aid in all the Nordic countries is the move towards commercial legal expenses insurance. Another is the development of third sector legal aid initiatives in Denmark and Norway, and to a lesser extent in Finland and Sweden. Such third sector initiatives have striven to alleviate deficiencies in the public legal aid schemes and, in particular, shortcomings in the way these schemes function in relation to the welfare state. Legal aid provided through third sector initiatives comprises a major part of the total legal aid provided in the Nordic countries. In Norway, it has been estimated that they deal with about 250,000 cases annually, while the public-sector scheme provides legal aid in around 33,000 cases. In view of this, the role of third sector initiatives calls into question perceptions of how the Nordic legal aid schemes relate to welfare state ideology. Both the amount and nature of legal aid provided indicate that there are flaws in the Nordic legal aid schemes, since they fail to provide comprehensive and all-encompassing 
social support. We will now go on to discuss how these third sector organisations work, and manage to reach their target groups in different ways than those used by traditional judicare offices and public legal aid.

Third sector legal aid institutions can be divided into two types. On the one hand, the third sector includes membership groups, such as health organisations, tenants' associations and labour unions. In a welfare state perspective, one consequence of this is that people who have resources - both financial and social — in that they consider joining such organisations - will have easier access to expert legal advice and organisations that can take up the cases. Membership organisations can give a form of outreach legal aid to their members by informing them about legal issues of relevance to them through various platforms and magazines. They can also help their members in the first phases of the naming process, and assist them in making a social problem into a legal issue. Because these organisations work at a very specialised level, they can choose when and how to use the court system for bigger political battles, to promote their specific agendas. To advance their cases against public bodies, membership organisations can use their legal knowledge together with empirical data about the lives of their target group.

On the other hand, we find various smaller organisations-especially in Norway and Denmark - that specialise in providing legal aid to some of the most marginalised groups in society. Legal aid for such people is thus left to third sector organisations and legal clinics, as we have seen in the chapters on Gadejuristen [The Street Lawyers] and the Norwegian Juss-Buss. Without volunteers and third sector initiatives, many of the most disadvantaged would lack any means to access the legal system. The smaller organisations are highly innovative, but dependent on volunteers and various forms of funding. These third sector initiatives use untraditional methods, such as outreach legal aid work, which is The Street Lawyers' way of handling clients, or focus on particular client groupsJuss-Buss, for example specialises in legal aid for prisoners. Because of this concentration on different target groups, there are different kinds of outreach work. The organisations' knowledge about the intertwined web of regulations affecting the target groups, and their understanding of the working principles of public authorities, as well their close familiarity with the lives and problems of the target clients make them specialists in 
their fields (Olesen et al. 2017). Outreach legal aid initiatives like The Street Lawyers, or Juss-Buss's prison project, like the membership organisations mentioned above, are very often based on thorough knowledge of their target groups' life situations. They have adopted ways of dealing with marginalised groups that are designed more to meet the users' needs than to fit into specific welfare structures, as is shown by how The Street Lawyers operate. First, they are involved in the initial 'troubles-talks' (Jefferson 1988) where a social problem can be named, blamed, and claimed, and transformed into a legal issue (Olesen et al. 2016). To be able to enter into such talks, the organisations have developed various trust-building techniques to approach their target groups. Second, the organisations take the troubles-talks seriously, and offer to take legal action to claim the target groups' rights from the relevant authority. Outreach legal aid consists of more than legal work: it also involves giving practical advice on navigating bureaucratic systems, providing information about opening hours, and establishing channels of communication by, for example, handing out free cell phones to facilitate contact between the client and the public authorities at the necessary times. Third, organisations such as The Street Lawyers work to empower their user groups by raising their legal awareness and increasing their knowledge of their rights. It can generally be said that the third sector, both volunteer organisations and membership groups, become attuned to their target groups' needs through specialisation and detailed knowledge of their lives.

Legal clinics play a major role as legal aid providers for the poorest people in the USA and in Europe, as Wilson notes in Chap. 11. In the Nordic countries, by contrast, the Norwegian Juss-Buss is one of few legal clinics to be found. The increase in legal clinics in Europe reflects an attempt to educate law students in a more practical manner, and at the same time help vulnerable groups, as happens in the USA, where almost all the nation's 198 accredited law schools have more than one clinic, and almost half of all law students participate in clinical work. Wilson reports that the number of European legal clinics is growing. Although many of the clinics did not begin operations until after 2011, one survey has identified 51 clinics in Western Europe (see also Piana et al. 2013). However, apart from Juss-Buss, Clinical Legal Education is not well integrated into law schools in the way it is in the USA. 


\section{Individualisation of Legal Aid}

Although many of the welfare laws in the Nordic countries are based on the universal welfare paradigm, there is no requirement that the most disadvantaged should be informed about their rights, and thus enabled to claim them. The literature on legal aid discussed throughout this book clearly demonstrates that legal aid schemes should compensate for this legal deficit, but even though legal aid exists, there is no guarantee that it will reach everyone who needs it. On the contrary, several chapters in this collection show that there need to be interpersonal encounters between the law and the person who needs to claim his/her rights, and that the visibility and attractiveness of these 'meeting points' depends on the resources of the individual person.

As discussed above, various kinds of physical interpersonal legal aid encounters have been developed. Several new ways of delivering legal aid in the Nordic countries have been mentioned in this collection. The chapter on The Street Lawyers and the chapter on ex-prisoners both discuss the process of naming, blaming, and claiming (see also Olesen et al. 2016). Legal aid often needs to be offered even before a legal problem has been identified, because many of the most vulnerable people in society struggle to understand and voice their complex problems and therefore tend to fail to seek legal advice and take legal action. However, efforts to provide outreach legal aid are often hampered by the difficulty of reaching target groups (Mathiesen 1975). One approach to extending legal aid would be by setting up informal discussions to identify the most appropriate way to refer clients to the relevant legal and non-legal systems. The Street Lawyers approach their target group through informal conversations and troubles-talk, as does the Legal Aid Centre described by Olesen. The Legal Aid Centre's gatekeeper-function has proved to be useful in the clients' naming, blaming, claiming process, as increasing numbers of clients use the Centre as a source of referral, follow through on the referral, and take up the relevant referral.

One notable development in the Nordic countries is that, to cut costs, the public authorities' encounters with citizens have been digitalised. In all the countries, except for Finland, legal aid mostly does not cover disputes with public authorities, even though they administer most welfare law. 
The rationale behind this is that the public authorities have advisory obligations towards citizens. However, with the introduction of cost-cutting measures, and the drive to make public administration more efficient, several initiatives have begun to offer online services. The most basic of these is the provision of information about welfare rights and procedures online, on the webpages of public authorities. Such information is often very basic, and does not cover more complex cases involving several legal areas. Yet, while there is the intention to provide information on legal rights online, it is still up to the individual to name a problem and transform it into a legal issue. If their life situations are difficult, and they lack resources, people are not usually able to find the right information and act upon it. They need a professional to turn the problem into a legal case. The unintended consequence of the use of IT solutions is that they make it harder for the most marginalised and vulnerable people in society to claim their rights. Advanced online and telephone services, such as those offered by the public legal aid offices in Finland, have the disadvantage that citizens need to make use of the technology, and be able to acknowledge and name a problem in legal terms.

Another issue that is discussed throughout the book is how legal aid relates to welfare rights, dispute resolution, and access to justice. Legal aid in the Nordic countries has been framed as a welfare right, rather than being viewed from the perspective of access to justice. With the creation of the Nordic welfare states after World War Two, the process of juridification accelerated in the Nordic countries, as legislation ensuring people's rights to welfare proliferated. Both the law and decision makers were affected by changes in the welfare state, which —as noted by Weber (1978) in his description of modern law-went from being based on relatively clear rules containing little discretion for the civil servant, to being much more complicated, with the possibility of considerable discretion, and of decisions being based on the views of professionals such as social workers and psychologists, as well as legal experts. With the transformation of the law, other professional groups entered the legal sphere, and new forms of governance in the public sector challenged legal decisions with extra-legal dimensions (Aubert 1976, 1989; Sand 1996; Bertilsson 1995; Hammerslev 2003). Most legal aid outside the courts relates to welfare law, which is getting ever more complex, and opening the way for a greater degree of 
discretion for case workers and leading to extra-legal complications and professional battles. The extension of written law into hitherto unregulated areas, either through an expansion of the law, or through more detailed regulation of something which was not previously legally regulated can-as Habermas (1987) points out—be seen as society's attempt to protect its citizens against the deficits of capitalism. With the individualisation of legal claims to entitlements guaranteed by welfare law, it becomes the responsibility of the individual to claim his or her rights. However, the institutionalisation of welfare rights through welfare laws individualises claims, even though they address problems of a collective nature. The skills required to claim one's rights are distributed unevenly among different groups in society. Most people need legal aid to turn an acknowledged problem into a claim that can be petitioned under the conditions specified in formal law. As Papendorf argues in Chap. 12, this highlights the bureaucratic and distanced organisation of the law, which makes it difficult to claim rights if you do not know about them, and if you do not have the resources to claim your rights in a bureaucratic welfare system. This means that the welfare rights that should protect citizens needing support actually distance them from the public bodies that should provide aid (see also Papendorf 2012).

In Chap. 10, Johnsen examines how legal aid moves from being a welfare paradigm to one of human rights. The European Union (EU) and the Council of Europe focus on 'access to justice' through the European Convention on Human Rights and the EU Charter of Fundamental Rights. The EU rules, however, can be viewed as being focused on the institutional set up, i.e., on how citizens get access to justice via the court system, without acknowledging that legal aid often concerns basic welfare rights that could be claimed more easily from the relevant authority. Human rights protect citizens from the state, and secure their rights, but legal aid is becoming an individual project to oblige states to follow minimum standards. The welfare paradigm of legal aid may therefore be challenged by individualising rights, which leaves the most vulnerable even more distanced from the law, as Papendorf claims in Chap. 12. He argues that the impact of this shift towards rights legislation has been to link the use of the law to individuals' situations and their ability to mobilise their rights. Satisfying legal conditions entails redefining everyday situations, i.e., living situations have to be recast-or named, blamed, and claimed - in the language of the law by individuals themselves, to be 
able to approach the system. Moreover, the authorities' solution is to abstract human beings from their situation, to bend them to the rules and treat them bureaucratically. This gives unequal access to justice and leaves little room for welfare with care professionals 'squeezed between growing demands and insufficient budgets', as Papendorf puts it. With greater scope for discretion in the public sector, when citizens are given aid, such extra-legal factors as budgetary considerations and administrators' workloads can become important.

Thus, compensatory legal aid requires not only qualified assistance, but also a strengthening of justice seekers' participatory abilities, so they avoid alienation. Legal aid projects with a proactive profile are rare, because they demand considerable resources, but they have in fact increased in the Nordic countries, through the third sector. However, because the third sector often targets particular groups in society, proactive aid is selective; but nonetheless, it responds to real needs and targets them.

\section{Conclusion}

All the Nordic countries have public legal aid schemes founded upon a core welfare state model. Such schemes face the twin challenges of cost and effectiveness. To a varying extent, the public schemes have adjusted the welfare state model in the face of these challenges, but failed to fully meet them. A reconfiguration of the legal aid scheme has thus taken place, bringing in third sector legal aid providers. These are more sensitive to legal aid needs, and consciously strive for better ways to cater for those unable to take advantage of the public schemes. However, the increasing role of the third sector represents a shift away from the traditional welfare state ideology of the Nordic countries and also fails to offer the inclusiveness and all-encompassing effects normally attributed to a well-functioning welfare state support scheme. This becomes even more significant when the move towards the marketisation of legal aid through legal expenses insurance and membership organisations is factored in. These developments take different forms, so no such thing as a Nordic model of legal aid exists.

The area of legal aid might thus be seen as representing a flaw in the Nordic welfare state model. The general social support schemes of welfare states, which are governed by a bureaucratic system regulated by laws and 
regulations, remain inaccessible to those in most need of support, and the welfare state system itself fails to provide the legal aid needed to access universal welfare rights.

We have shown how welfare ideology focuses on the structure of people's needs, problems, and well-being, and ask how legal expertise can help, whereas the access to justice perspective is mainly concerned with people's rights, and their ability to use a specific institution - the courtsto solve problems. The access to justice perspective focuses less on whether the courts can provide citizens with solutions to their problems in an efficient way. Seen in a welfare perspective, access to justice thus depends on the substantive content of people's rights, and the existence of nonimplemented rights that can be made operational through better access to the courts. The access to justice perspective does not solve the actual challenge of transforming a social problem into a legal issue through naming, blaming, and claiming processes.

While even the Nordic states have abdicated responsibility for legal aid, new organisations have taken over. They are organised differently than traditional legal aid offices, and understand the target groups needs better; they are able to meet their target groups in different settings and help transform social problems into legal problems, so that they can then claim the clients' rights. Thus, as seen in several of the chapters, alternative legal aid providers are innovative: they employ new methods to improve access to legal assistance, based on knowledge of the target groups needs, the effectiveness of different legal aid strategies, and the workings of the legal system. This might provide a basis for reform of the public system that would produce a public legal aid scheme, which, in keeping with welfare state ideology, would provide access to the law for everyone.

\section{References}

Arts, W. A., \& Gelissen, J. (2010). Models of the welfare state. In S. Leibfried, F. G. Castles, J. Lewis, H. Obinger, \& C. Pierson (Eds.), The Oxford handbook of the welfare state (pp. 569-585). Oxford: Oxford University Press. Aubert, V. (1976). The changing role of law and lawyers in nineteenth- and twentieth-century Norwegian society. In D. N. MacComick (Ed.), Lawyers in their social setting (pp. 1-17). Edinburgh: Green. 
Aubert, V. (1989). Continuity and development in law and society. Oslo: Scandinavian University Press.

Bertilsson, M. (Ed.). (1995). Rätten i Förvandling. Jurister mellan stat och marknad. Stockholm: Nerenius \& Santerus Förlag.

Felstiner, W. L. F., Abel, L. R., \& Sarat, A. (1980/81). The emergence and transformation of disputes: Naming, blaming, claiming. Law \& Society Review, 15(3/4), 631-654.

Galanter, M., \& Palay, T. (1991). Tournament of lawyers: The transformation of the big law firm. Chicago: University of Chicago Press.

Goul Andersen, J., \& Larsen, C. A. (2015). Hvad er universalisme? In J. Goul Andersen \& C. A. Larsen (Eds.), Den universelle velfardsstat: Funktionsmåde, folkelig opbakning og forandring (pp. 13-29). Frederiksberg: Frydenlund Academic.

Habermas, J. (1987). Theory of communicative action: A critique of functionalist reason (Vol. 2). Cambridge: Polity Press.

Hammerslev, O. (2003). Danish Judges in the 20th century: A socio-legal study. Copenhagen: DJØF Publishing.

Heinz, J. P., Laumann, E. O., Nelson, R. L., \& Michelson, E. (1998). The changing character of Lawyers' work: Chicago in 1975 and 1995. Law \& Society Review, 32(4), 751-776.

Jefferson, G. (1988). On the sequential organization of troubles-talk in ordinary conversation. Social Problems, 35(4), 418-441.

Kilian, M., \& Regan, F. (2004). Legal expenses insurance and legal aid-two sides of the same coin? The experience from Germany and Sweden. International Journal of the Legal Profession, 11(3), 233-255.

Kongshøj, K. (2015). Den nordiske velfærdsmodel: veje til og fra universalisme i Danmark, Finland, Norge og Sverige. In J. Goul Andersen \& C. A. Larsen (Eds.), Den universelle velfardsstat: Funktionsmåde, folkelig opbakning og forandring (pp. 159-178). Frederiksberg: Frydenlund Academic.

Mathiesen, T. (1975). Noen konlusjoner om rettshjelp, rettspolitikk og samfunnsstruktur. In A. Eidesen, A. Eskeland, \& T. Mathiesen (Eds.), Rettshjelp og samfunnsstruktur (pp. 187-206). Oslo: Pax.

Moorhead, R. (2004). Legal aid and the decline of private practice: Blue murder or toxic job? International Journal of the Legal Profession, 11(3), 159-190.

Olesen, A., Minke, K. L., \& Hammerslev, O. (2016). Det retlige møde. In Festskrift til Sten Schaumburg-Müller. København: Jurist- og Økonomforbundets Forlag.

Olesen, A., Nielsen, S. P. P., \& Hammerslev, O. (2017). Gadejura - kunsten at fremelske gadefolkets oplevelse af at bære rettigheder. In N. J. Clausen (Ed.), 
Festskrift til Hans Viggo Godsk Pedersen (pp. 435-455). København: Jurist- og Økonomforbundets Forlag.

Papendorf, K. (2012). Rett for alle? Rettsliggjøring og rettsferne personers mulighet til a mobilisere retten. Oslo: Novus forlag.

Piana, D., Langbroek, P., Berkmanas, T., Hammerslev, O., \& Pacurari, O. (2013). Legal and judicial training in Europe. The Hague: Eleven International Publishing.

Regan, F. (2001). How and why is pro bono flourishing: A comparison of recent developments in Sweden and China. Law in Context, 19, 148-162.

Sand, I.-J. (1996). Styring av kompleksitet. Rettslige former for statlig rammestyring og desentralisert statsforvaltning. Bergen-Sandviken: Fagbokforlaget.

Sandefur, R. L. (2001). Work and Honor in the Law: Prestige and the Division of Lawyers' Labor. American Sociological Review, 66(3), 382-403.

Sommerlad, H. (2001). "I've lost the plot": An everyday story of the "political" legal aid lawyer. Journal of Law and Society, 28(3), 335-360.

Weber, M. (1978). Economy and society. Berkeley: University of California Press.

Open Access This chapter is distributed under the terms of the Creative Commons Attribution 4.0 International License (http://creativecommons.org/ licenses/by/4.0/), which permits use, duplication, adaptation, distribution, and reproduction in any medium or format, as long as you give appropriate credit to the original author(s) and the source, a link is provided to the Creative Commons license, and any changes made are indicated.

The images or other third party material in this book are included in the work's Creative Commons license, unless indicated otherwise in the credit line; if such material is not included in the work's Creative Commons license and the respective action is not permitted by statutory regulation, users will need to obtain permission from the license holder to duplicate, adapt or reproduce the material. 